\title{
An overview of Teletandem mediation courses for teacher education
}

\author{
Um panorama de cursos de mediação em Teletandem \\ para a formação de professores
}

\author{
Micheli Gomes de Souza ${ }^{1}$ \\ Maisa de Alcântara Zakir ${ }^{2}$ \\ Daniela Nogueira de Moraes Garcia ${ }^{3}$
}

\begin{abstract}
This paper aims to investigate practices in teacher education in the context of the Teletandem Brasil Project (Vassallo \& Telles, 2006). Through web conferencing tools, the project pairs up Brazilian university students learning foreign languages with foreign university students learning Portuguese. The partnerships are supported by mediation sessions conducted by professors and researchers of the Teletandem Project. In this paper, we present some theoretical concepts related to telecollaboration (Belz, 2003; O'Dowd, 2007; 2018), besides providing a detailed description and comparison of four editions of preparatory courses for teletandem mediators, organized by researchers of the project.
\end{abstract}

1. Universidade Estadual do Norte do Paraná. Jacarezinho, Paraná - Brasil. https://orcid. org/0000-0003-3111-9613. E-mail: souza.micheli@hotmail.com.

2. Universidade Estadual Paulista. Presidente Prudente, São Paulo - Brasil. https://orcid. org/0000-0002-1792-3026. E-mail: maisa.zakir@unesp.br.

3. Universidade Estadual Paulista. Assis, São Paulo - Brasil. https://orcid.org/0000-00032813-7538. E-mail: dany7garcia@gmail.com. 
The results of the analysis may provide alternatives for teacher education in a context of growing transcultural connections.

Keywords: Teletandem; Mediation; Teacher education; Course design.

\section{RESUMO}

Este artigo busca investigar práticas de formação de professores no contexto do projeto Teletandem Brasil (Vassallo \& Telles, 2006). Por meio de ferramentas de webconferência, o projeto emparelha estudantes universitários brasileiros que aprendem uma língua estrangeira com estudantes universitários estrangeiros que aprendem português. As parcerias são apoiadas por sessões de mediação conduzidas por professores e pesquisadores do projeto Teletandem. Neste artigo, apresentamos alguns conceitos teóricos relacionados à telecolaboração (Belz, 2003; O’Dowd, 2007; 2018), além de fazer uma descrição e comparação detalhadas de quatro edições de cursos para mediadores de teletandem, organizadas por pesquisadores do projeto. Os resultados da análise podem fornecer alternativas para a formação de professores em um contexto de crescentes conexões transculturais.

Palavras-chave: Teletandem; Mediação; Formação de professores; Elaboração de cursos.

\section{Introduction}

The use of technology for foreign language learning and teaching has increasingly demanded new perspectives and attitudes towards teacher education. Language teachers' competences require special attention as they constitute a crucial factor in the educational computerassisted language learning (CALL) scenery.

Creating educational contexts and experiences that integrate the use of technology for language teachers has been of great need in such a globalized era. It is not only about the expertise and training for teachers, but it is about making them experience themselves the potential of tools and opportunities that go beyond language, space and time. By doing this, it is possible to provide teachers with meaningful 
insights, reflection, confidence, autonomy and inspiration in order to enhance their pedagogy.

Avalos (2011, p. 11) points out that the professional development of teachers is understood in the relevant literature as a process of learning how to learn and how to transform knowledge into practice for the students' growth. Internet and new technologies have shifted patterns and broaden perspectives towards people, languages and cultures. Scenarios in which intercultural communication is highlighted have been provided by the Computer Mediated Communication (CMC) and CALL and played a major role in pedagogical practices.

Ware and Kramsch (2005) state that web-based technologies have been advocated as promising examples of computer-based learning, providing language students with interactions across geographic, linguistic and cultural lines. According to the authors, the increasingly complex landscape that involves technology fosters cross cultural communication and creates scenarios that extend the language teacher's roles.

By recognizing telecollaboration as one of the essential CMC activities in foreign language, O'Dowd (2015) presents a model of competences for the telecollaborative teacher. He also presents UNICollaboration $^{4}$, an online platform, which has been developed to promote the design of tools and training courses for educators in this complex activity of online foreign language education. The author recognizes the lack of opportunities for in-service teachers in which they would be able to learn how to engage in new pedagogical practices.

Broader perspectives have been offered to foreign language teachers through new learning environments that are mediated by the computer. These perspectives can be reinforced by the association of image, voice and written resources (Vassallo \& Telles, 2009).

This paper aims at investigating a context in which the process of teaching and learning foreign languages can go beyond language and take on broader dimensions as students take part in the organization and construction of knowledge. Thus, we discuss possibilities to 
support teachers' educational process in which mediation sessions play a major role. In the first part, we mention telecollaboration definitions for this paper. Then we explain tandem and teletandem ${ }^{5}$ learning to reach interaction and mediation sessions. Later we focus on mediation sessions and the mediator's role, by describing the preparatory courses that have been offered to promote reflection on the aspects embedded in the teletandem context. We conclude this article by reinforcing the importance of new scenarios and tools to support teacher education process as well as perspectives for new editions of the courses offered for teletandem mediators.

\section{Telecollaboration}

According to Belz (2003a), telecollaboration comprises global computer networks to foreign (and second) language learning and teaching in institutionalized settings for internationally-dispersed learners that use it in parallel to language classes in order to support social interaction, and intercultural exchange. The author also states that "telecollaboration is characterized by institutionalized, electronically mediated intercultural communication under the guidance of a languacultural expert (i.e., teacher) for the purposes of foreign language learning and the development of intercultural competence" (Belz, 2003, p. 2).

For O'Dowd and Ritter (2006), telecollaboration comprises "the use of online communication tools to bring together language learners in different countries for the development of collaborative project work and intercultural exchange" (2006, p. 623).

Our understanding for this paper embraces the term telecollaboration, which is used by Ware \& Kramsch (2005), to refer to the language mediated by technology and intercultural contact. Based on Belz and Thorne (2006) and O'Dowd (2007), Belz and Vyatkina (2008) consider it as a language learning configuration in which distant learners use

5. In this article, we write "teletandem" in lower case when it refers to the activity or to the context. When the term refers to the project (or program, as it is currently understood, due to its importance and growing number of institutional partnerships), it is written with a capital T, "Teletandem". 
internet communication tools for social interaction, dialogue and debate between partners, native or proficient speakers, in the same age average.

O’Dowd (2018), O'Dowd and Beaven (2019) use virtual exchange as an umbrella concept to refer to telecollaborative educational practices. According to the authors, virtual exchange "involves peopleto-people technology-enabled communication, engaging individuals from diverse cultural backgrounds who are geographically distant in meaningful conversations, with the support of educators" (O'Dowd \& Beaven, 2019, p. 15). Therefore, telecollaboration or on-line collaborative practices comprise the same idea as a virtual exchange modality and can be interchangeably used in the present study.

Literature has shown that telecollaboration can enrich and maximize pedagogical practices performed in classrooms and also help students to become responsible for their learning goals, to develop reflexivity and intercultural competence when paired to foreigners and to be aware of issues concerning identity, language and culture. This kind of practice demands an active and critical role of teachers in the process of mediating learning partnerships. In telecollaborative practices, teachers are faced with potential tools that bring together language learning, cultural awareness and effective use of technology.

The present study emphasizes teletandem as a telecollaborative context which impacts the process of teaching/learning languages and teacher education towards a global dimension. Garcia (2012), by investigating initial contacts between teletandem partners, underlines teletandem as a context that fosters reflective attitudes. The author states that the participants of her investigation were pre-service teachers and that the teletandem telecollaboration permitted them to experience different situations of teaching/learning, broadening their view and critical-reflective attitude. The great motivation towards the contact with the foreign language and speaker is also emphasized in the study.

Based on such results, this paper intends to explore telecollaboration in teletandem and mediation sessions in order to encourage students who will be future teachers, as well as in-service teachers, to provide a scenario of sharing, reflecting, growing, experiencing and selfevaluating as part of their development. 


\section{Teletandem principles, research interests and interactions' characteristics}

Teletandem context of telecollaborative language learning is theoretically grounded on the principles of tandem learning, in which two people with different mother tongues or languages of proficiency work together to learn one another's language (Little et al, 1999, p. 1). Three principles constitute its bases and can contribute to the success (or not) of the partnership (Schwienhorst, 1998).

The first one is reciprocity, which implies that each learner should equally benefit from the partnership by giving and receiving help. An agreement between partners is expected, as well as the devotion of the same amount of time to his/her and to the partner's language. For Brammerts (2003), the partnership will last only if both partners benefit from it and support each other when learning.

The separated use of languages is another principle and is closely related to reciprocity. Each language should take the same place in the session and should not be mixed. According to Vassallo and Telles (2006, 2009), this principle aims to motivate and challenge the students towards the target language.

The third principle in tandem learning is autonomy. It confers learners the opportunity to set their own goals for their work in tandem, and to think about how these goals may be reached in collaboration with their tandem partners. (Brammerts, 2003, p. 33)

In 2006, the Teletandem Brasil Project started its activities to fulfill the needs and gaps in foreign language learning. As a variation on tandem language learning, "teletandem is a virtual, collaborative, and autonomous context in which two speakers of different languages use the text, voice, and webcam image resources of VOIP technology (Skype, Google Hangouts, Zoom) to help each other learn their native language (or language of proficiency) "' (Telles, 2015, p. 603).

According to the project website ${ }^{6}$, teletandem can be defined as:

- a sum of opposites, such as sociability and individualization. 
- an online collaborative joint endeavor with a partner aimed at learning a foreign language.

- a global balanced context within which partners' relationships can relay roles of power.

- an online context within which one can take responsibility of and socialize learning in reciprocal and autonomous ways.

- an online context within which one can exercise autonomy and manage one's own learning process.

- an online context with space for one's pleasurable relationship.

- a joint endeavor that consists of online regular meetings extended over a specific time period.

At its first steps, the Teletandem Brasil Project embraced a great number of research studies into three main investigation fields: 1 . Teletandem as a learning tool; 2. Interaction between teletandem partners; 3. Teletandem as a context for foreign language teacher education. Currently, some concepts such as transculturality (Welsch, 1994), interculturality and multiculturality were added, focusing on: 1. The ways to understand foreign languages study, learning and practice; 2. The ways to understand the partner's culture and the impacts on the learning; 3. The contributions of teletandem to education and the relation to other people; 4 . Different views of teletandem institutional implementation. (Telles \& Ferreira, 2011)

The dissertations and theses that constitute the literature of the Teletandem Brasil Project include themes related to the learner's autonomy (Cavalari, 2009; Luz, 2009); to the agreement and negotiation processes (Garcia, 2010), power relations and conflicts (Vassallo, 2010); clash of cultures and languages and intercultural competence (Mendes, 2009); mediation sessions and the professor mediator (Cândido, 2010; Salomão, 2008; Elstermann, 2017); learning and communication strategies in teletandem contexts (Silva, 2008); beliefs and social representations (Bedran, 2008; Funo, 2011; Mesquita, 2008; Silva, 2010); language teaching education (Kaneoya, 2008; Broco, 2014); grammar and teaching material for Portuguese as a 
foreign language teaching (Brocco, 2009); linguistic characteristics in teletandem interactions (Rossi Dos Santos, 2008; Franco, 2016); oral performance (Furtoso, 2011; Freschi, 2017); culture (Zakir, 2015; Freitas, 2015; Salomão, 2012); misunderstandings (Souza, 2016); performativity and gender issues (Costa, 2015); identity and mediation sessions (Funo, 2015).

The Teletandem activities (research, practice, establishment of partnerships, events etc.) have been carried out by professors, undergraduate and graduate researchers from São Paulo State University (UNESP), in partnerships with other Brazilian and foreign universities. At UNESP-Assis campus, context focused in this article, the Teletandem team establishes communication with Departments of Portuguese Language abroad to promote teletandem partnerships. When the timetable is set, some guidelines concerning teletandem and technological issues can be given to students if necessary. After that, the team pairs up Brazilian university students learning English and foreign university students learning Portuguese by using Internet interaction and multimedia tools.

The teletandem interaction can be described as follows:

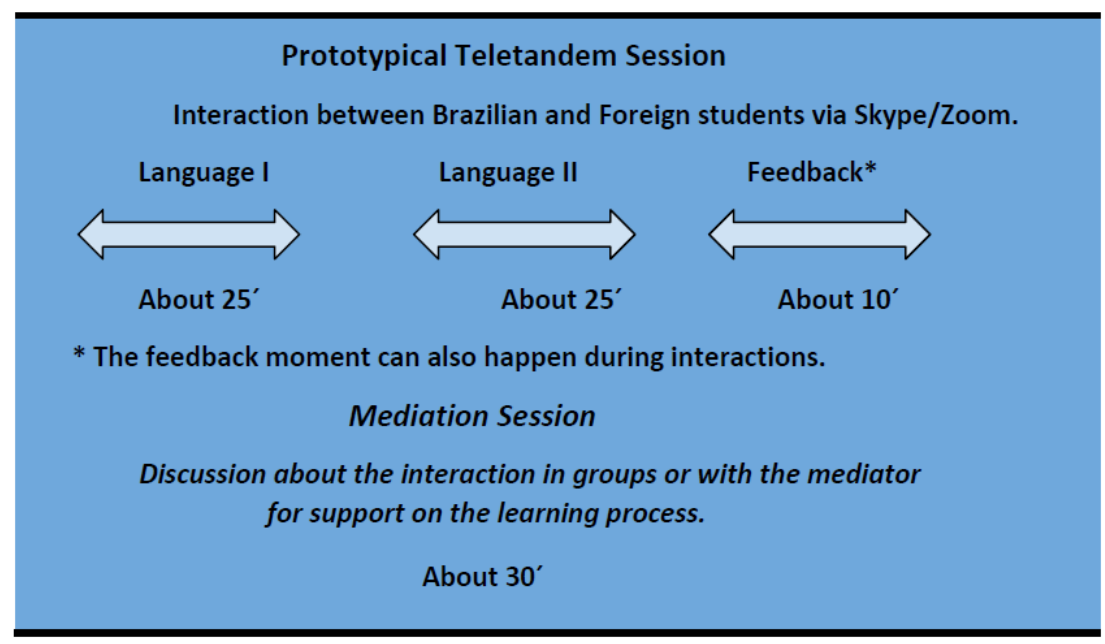

Figure 1 - Prototypical Teletandem Session (Adapted, Garcia, 2013) 
In the context of institutional partnerships between UNESP-Assis and Departments of Portuguese in universities abroad, the foreign context constitutes an integrated teletandem modality (teletandem takes part in the curriculum of a language course). On the other hand, the referred Brazilian context consists of a non-integrated teletandem modality. It means that teletandem is not part of syllabus, but the institution offers support to the participants (language lab, mediators, logistics for the establishment of the partnerships etc.), as Cavalari (2018) points out. Therefore, at UNESP-Assis most students who practice teletandem are not necessarily students from a specific language course and do it as an "extracurricular" activity. Due to this characteristic, these volunteer students receive pedagogical support from mediators who are not necessarily their language teachers. On the other hand, students who conduct their partnerships within the scope of a language course, as in the integrated mode, can be directly mediated by their language instructors and this mediation happens along with the goals of the language course.

\section{Teletandem mediation}

Considering the great diversity of teletandem modalities (Aranha \& Cavalari, 2014), the roles of mediators can vary greatly according to the specificities of each one of them. In the case of non-integrated teletandem, which we focus in this article, the engagement expected from the educators has an essential impact on the mediation process. At UNESP-Assis, mediation is considered the pedagogical support and management of the partnerships conducted by the mediators during the whole process. It can be conducted by professors from the Modern Languages and Education departments, researchers of the Teletandem Brasil program and undergraduate students of Languages and Literatures engaged in the teacher education process ${ }^{7}$.

\footnotetext{
7. Mediation has been on the scope of Teletandem research studies since the beginning of the project. In one of the first papers on this theme, Salomão (2008) analyzed the process and strategies used by a mediator in the context of UNESP - São José do Rio Preto campus, and the implications of mediation in relation to a perspective of education within practice. Candido (2010) considered the context of UNESP-Assis focusing on how pedagogical support was offered to students through orientation sessions.
} 
Funo (2015) explains that mediation in teletandem is based on principles of sociocultural theory (Vygotsky, 1991). Therefore, according to the author, the concept of mediation assumes that mediator and learner are "(a) able to recognize characteristics of a given stage of linguistic proficiency or cultural learning; (b) are able to understand that these characteristics change and, then, concomitantly, (c) are able to notice that the learners and their perspective about their development are also changed." (Funo, 2015, p. 39-40). The author also emphasizes that the practices of mediation vary as the circumstances change (subjects, context, levels of proficiency, goals etc.). So, there is not a closed and stable definition of mediation, but in the context of UNESP-Assis it has been associated to orientation sessions that happen before and/or after each teletandem interaction between partners during the whole process of partnership. These sessions have happened as moments for the learners to share their issues about the interpersonal relation with their partners, their learning process, to receive pedagogical support of the mediator regarding learning strategies, negotiation of meaning and to reflect about discursive and cultural issues that emerge in their teletandem dialogues.

According to Elstermann (2017, p. 135), "There is still no consistent mediation concept which the teletandem mediators in charge use [...]. Each mediator has a slightly different view of the mediation session and, therefore, guides them in different forms." In the context of the non-integrated partnerships, which Elstermann describes, this diversity is due to the varying conditions in which the mediation is promoted. For foreign language learners at UNESP-Assis, for example, since 2014 most partnerships have been established as a non-integrated modality. For this reason, the need for mediators has increased, since the sessions are not part of the curriculum of a specific language class, condition that could demand mediation by a corresponding professor. Offering sessions before or after students' regular classes also imposes the need for a higher number of mediators committed to support the organizational and pedagogical aspects of the interactions.

In order to meet the high demand of mediators at UNESP-Assis, the mediation process has been conducted in different formats. Its main part has been the face-to-face conversation sessions between Brazilian students and the mediator of each group, right after each teletandem 
interaction. These sessions have usually lasted about 30 minutes and have been characterized as a means to discuss and raise learners' awareness for the necessity of reflecting about the learning processes in teletandem. The short duration of this on-site session aims at adjusting to the schedule of mediators and students, who are usually engaged in different academic activities. Elstermann (2017) also describes other means for the conduction of the mediation sessions, such as electronic learning platforms (Moodle or TelEduc) and closed Facebook groups. Recently, based on our experience in the last 2 years, we can include an increasing use of WhatsApp, due to its widespread use among students at UNESP-Assis.

Garcia and Souza (2018), in a case study about mediation in a closed Facebook group, emphasize the role of the mediator in encouraging learners' motivation and attention to the teletandem principles. Through motivational messages and direct guidelines about strategies and procedures, the mediator played an important role in engaging learners in the partnerships. In this case study, Facebook was an alternative to manage the difficulty of having students in a face-to-face mediation session, due to the time of the interactions, which were conducted during lunchtime in Brazil. Besides that students doing teletandem at UNESP-Assis usually have to adjust to different schedules of sessions due to the daylight-saving time changes.

Considering the complex contexts of mediation, in both the traditional synchronous and asynchronous sceneries, we understand the role of the mediator in institutionalized interactions as essential to raise learner's awareness about linguistic-discursive and cultural issues that emerge in the dialogues through teletandem. In this regard, the possibility of using different tools and adjusting to the constraints of each institutional partnership requires a deep perception about the characteristics of communication and mediation in teletandem, which differ in great extent to the known context of a traditional classroom.

As mentioned before, a high level of understanding on teletandem specific demands is mandatory to the offer of mediation. In order to fulfill this need, raise awareness and comprise knowledge on teletandem's issues, preparatory courses have been designed by experienced mediators and researchers since the first years of the Teletandem project. 
For the purpose of this article, we focus on four editions of the courses (2014 to 2017). These courses were initially designed to meet the great demand to prepare mediators for the growing number of partnerships at UNESP-Assis, resulted from the consolidation of teletandem practice in this campus and in its partner institutions.

\section{Preparatory courses for teletandem mediators}

In this section, we analyze the main characteristics of four editions of the courses for teletandem mediators ${ }^{8}$, based on our experience as members of their organizing committee. We aim at describing the configuration of the courses held from 2014 to 2017, considering their focuses, approaches and contributions for the education of teachers engaged in mediation of telecollaborative learning partnerships like teletandem.

In the following table, we present the main characteristics of the courses, considering the format, main activities, tools, workload and number of participants of each edition. Those characteristics may vary according to identified needs such as the participants' backgrounds, availability of tools and pedagogical demands of different mediation contexts.

8. Before the editions focused here, other mediation courses, workshops and meetings had also happened in the context of UNESP-Assis. However, we focus on the 2014-2017 editions due to their importance to the context of growing demand for teletandem mediators and due to the possible access to the data saved in digital platforms and published in a blog. 
Table 1 - Overview of the preparatory courses for teletandem mediators

\begin{tabular}{|c|c|c|c|c|}
\hline & 2014 Edition & 2015 Edition & 2016 Edition & 2017 Edition \\
\hline Format: & Blended & Online & Online & Online \\
\hline Activities: & $\begin{array}{l}12 \text { hours - face- } \\
\text { to-face course } \\
10 \text { hours - } \\
\text { mediation } 8 \\
\text { hours - online } \\
\text { analysis of } \\
\text { excerpts of } \\
\text { teletandem } \\
\text { sessions }\end{array}$ & $\begin{array}{l}8 \text { hours - } \\
\text { Videoconference } \\
\text { course } \\
12 \text { hours - } \\
\text { readings of } \\
\text { teletandem } \\
\text { articles }\end{array}$ & $\begin{array}{l}8 \text { hours - } \\
\text { Videoconference } \\
\text { course } \\
4 \text { hours - } \\
\text { analysis of } \\
\text { excerpts of } \\
\text { teletandem } \\
\text { sessions }\end{array}$ & $\begin{array}{l}8 \text { hours - } \\
\text { Videoconference } \\
\text { course } \\
2 \text { hours - online } \\
\text { analysis of excerpts } \\
\text { of teletandem } \\
\text { sessions } \\
20 \text { hours - mediation } \\
\text { (observation and/ } \\
\text { or conduction) } \\
\text { and report of } \\
\text { each mediation } \\
\text { session observed or } \\
\text { conducted. }\end{array}$ \\
\hline Tools: & Blogspot & $\begin{array}{l}\text { Zoom } \\
\text { Blogspot }\end{array}$ & $\begin{array}{l}\text { Zoom } \\
\text { Blogspot } \\
\text { Google Docs }\end{array}$ & $\begin{array}{l}\text { Zoom } \\
\text { Blogspot } \\
\text { Google Docs }\end{array}$ \\
\hline $\begin{array}{l}\text { Date of } \\
\text { face-to-face } \\
\text { or online } \\
\text { meetings }\end{array}$ & $\begin{array}{l}\text { May } 05,12,19 \\
\text { and } 27\end{array}$ & $\begin{array}{l}\text { September } 24 \\
\text { and } 25\end{array}$ & September 5 & $\begin{array}{l}\text { August } 31 \text { and } \\
\text { September } 14\end{array}$ \\
\hline Workload: & 30 hours & 20 hours & 12 hours & 30 hours \\
\hline Participants $^{*}$ & 13 & 15 & 19 & 17 \\
\hline
\end{tabular}

*This number refers to the participants who concluded the course and received a certificate. The organizing committee and the professors responsible for the contents of the courses are not included in this number. The courses were offered by several researchers and professors from the Teletandem program, including the authors of this article. Their names can be consulted on the blog that hosts the content of the courses, indicated on the footnote below.

The 2014 Edition was conducted in a blended format. It was directed to undergraduate students majoring in Language and Literature Teaching (Portuguese, a foreign language and their respective literatures), from UNESP-Assis. The same participant's background has been observed in all editions, being most of them language students and researchers interested in telecollaboration. It has helped the team in the Lab to set more partnerships for teletandem practice and conduct teletandem sessions. This also reflected on further studies and careful teletandem sessions planning. The 12-hour face-to-face session was designed to present an introductory notion of key concepts and theoretical principles 
of teletandem practice and of mediation. A blog ${ }^{9}$ was created so that participants could access materials and activities proposed as well as post comments and do the course assignments. This blog was used as a database to keep the history and activities of all editions. The focus on participants from UNESP-Assis is also explained by the necessity of preparing new mediators to attend the growing number of institutional partnerships between UNESP-Assis and foreign universities (Garcia \& Souza, 2018).

Since 2015, the preparatory course for teletandem mediators at UNESP-Assis has been online. We have been using Zoom ${ }^{10}$ to connect participants who are interested in becoming a teletandem mediator. These online editions have enabled the participation of telecollaboration researchers and faculty members of teletandem partner institutions in different countries. Different formats have been tested since then: in 2015, the content of the course was developed in two afternoons, on September 24th and 25th. In 2016, the eight-hour program was presented in a single day, September 5th. In 2017, we opted for dividing the program into two different days but keeping the same day of the week. The 2017 edition was held in two Thursday afternoons, on August 31 st and September 14th.

The 2015 edition of the course for teletandem mediators focused on the pedagogical implications of recent research studies in teletandem. Basically, the idea was to present the results of Master theses and $\mathrm{PhD}$ dissertations concluded in 2015, which focused on the cultural dimension of teletandem sessions, to foster reflection on how to approach those findings in mediation sessions. There was also a section in which the organizational steps of establishing institutional partnerships were presented so that participants could have an overview of the whole process, from the moment of contacting the institutional partnership until the moment of getting feedback from the teletandem participants. Finally, there was a last section in which the mediator's role was discussed.

The 2016 edition focused on the teletandem interactions and offered participants an overview of the theoretical approaches that

9. https://mediacaoteletandem.blogspot.com.br/

10. zoom.us 
have been used to analyze data in recent research studies. We discussed the Dialogical Discourse Analysis, based on Bakhtin and the Circle's ideas; the Performativity Theory, grounded on Judith Butler's work; the Critical Discourse Analysis, grounded on Fairclough's studies; Focus on form and critical language awareness, based on Swain and Lepkin's proposal.

The topics discussed in 2016 were kept in the 2017 edition, but the participants were asked to attend at least four ongoing or upcoming teletandem mediation sessions in their institutions and to produce detailed reports of each one, sharing what they had experienced and reflected about in those sessions. Since the course preceded the beginning of teletandem sessions in the second semester of 2017, which are commonly carried out between September and November, the participants were expected to have the time to find the best options to accomplish the workload required in this part of the course.

As mentioned before, improvements and different attempts had been made in order to comprise participants' needs and contextual conditions. The attendance required in mediation sessions aimed at providing participants the opportunity to experience mediation beyond theory and to provide pedagogical and management support to professors and mediators of ongoing partnerships. Participants were told to join a teletandem group and offer support to the mediator or conduct mediations independently ${ }^{11}$. The importance of adding the participation in mediation as part of the course is also explained by the demand for new mediators for future teletandem partnerships.

According to a study conducted by Zakir and Colonheze (Mimeo), the number of partner institutions ${ }^{12}$ abroad and teletandem pairs of students has significantly increased at UNESP-Assis along the years in which the mediation courses were carried out. In 2015, there were 18 groups from 8 different universities abroad and 130 students could interact with their foreign partners; besides the institutional interactions,

11. Participants were also encouraged to experience teletandem in their foreign language, to better understand the characteristics of the learning and interactional processes that may emerge in the sessions. Most participants had already practiced teletandem or were teachers with experience in the field of language teaching.

12. A complete list of UNESP partner institutions can be found on the Teletandem program website, www.teletandembrasil.org. 
there were also 2 partnerships of autonomous teletandem sessions, in which each student could interact from home. In 2016, there were 26 groups from 12 different institutions and a total of 147 students from UNESP participated in teletandem sessions; in the same year, there were also 2 groups of autonomous teletandem sessions. In 2017, the number of students was much higher than in the previous years: a total of 270 students practiced teletandem in 22 group interactions from 11 different institutions around the world; in the same year, there were 3 groups of autonomous teletandem sessions. In 2018, there were 18 groups from 8 different institutions and 274 involved in practicing teletandem; there were also 6 autonomous groups along 2018.

The rising demand for mediators could also be seen in other institutions promoting teletandem. Based on our observation of participants' engagement in the mediation process, we believe this task was very useful as they could visualize the potential and challenges of the teletandem experience, build confidence and experience theory and practice. The three dimensions of the course, online lectures and discussion, excerpts' analysis and mediation practice, required a collaborative work by the organizers and long-term commitment to manage the participation of the mediators in their tasks.

Considering the activities suggested for the courses, the analysis of excerpts, which can be seen in 2014, 2015, 2017 editions, aimed at providing authentic material in which the students could realize issues that emerge from real teletandem interaction and mediation sessions. The analysis of excerpts of teletandem sessions and mediation, grounded on theoretical perspectives discussed in the courses, was an important and engaging activity in synchronous and/or asynchronous meetings of the courses. The excerpts were selected from research studies on teletandem focusing on issues that can emerge in teletandem interactions, such as generalizations about national cultures, negotiation of meaning, biased perspectives on social and regional inequalities, linguistic awareness, among others. The mediation of the analysis and discussion were carried out collaboratively by the researchers and professors in charge of the courses, all of whom experienced in teletandem practice, mediation, and research.

Using videoconferencing tools, such as Zoom, enabled us to reach researchers and mediators from different institutions. Among them, 
we can highlight the participation of Portuguese teachers abroad and foreign language teachers in Brazil in the initial process of implementation of teletandem in their contexts. In order to assist the participants abroad, the online meetings through Zoom were scheduled for the afternoons. Although Zoom enables a large number of participants online, we restricted the number of participants to 20, since one of the main goals of the course was to promote the debate and collaborative analysis of excerpts of mediation and teletandem interactions.

In the following figure, we have an example of the layout of the interactive context through Zoom. As we can see, it allows the use of voice, video camera and chat. Other resources used were "Shared Screen", for the lectures and the "Recording", to register the discussions. During the Zoom sessions of the course, we suggested the participants to "mute" their microphones when they were not talking. This helped to reduce or avoid noise during the oral presentations.

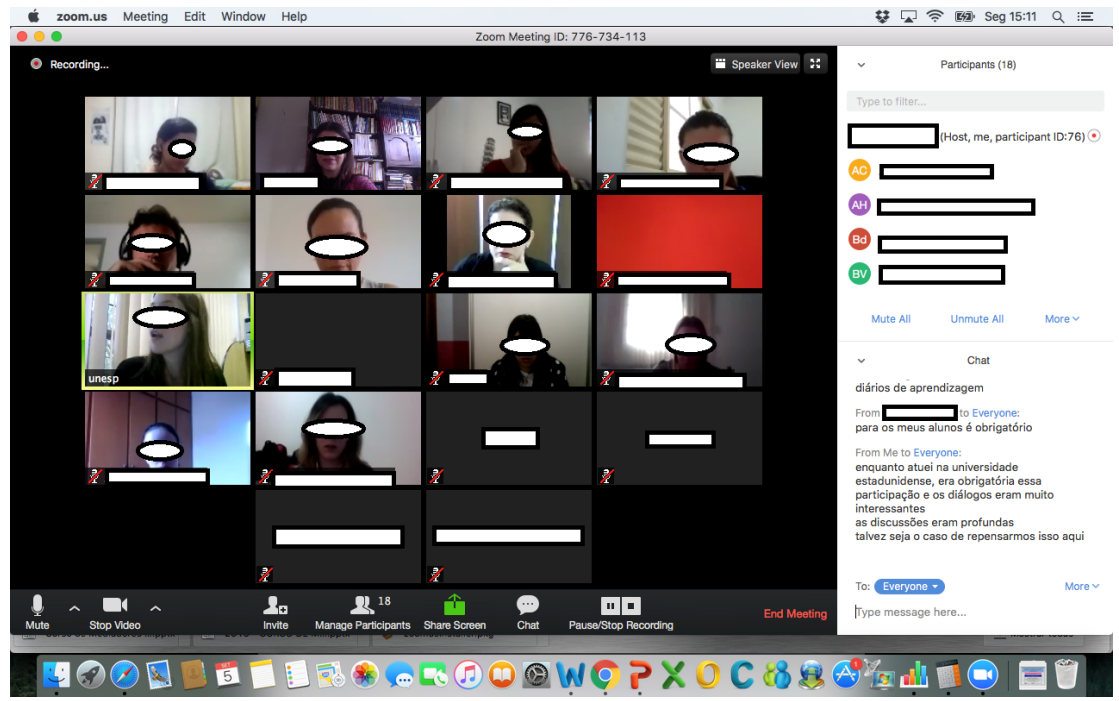

Figure 2 - Course environment on Zoom

Along with Zoom and Google Docs, the blog continued to be used to facilitate access to the material and activities of the course. All the editions were free of charge and the materials were of open access, sent to the participants' e-mail, shared through links or available on the blog. 
The organization of the courses has indicated the continuous necessity of discussing mediation in telecollaborative contexts, such as teletandem. The participants of the four editions contributed bringing their perspectives from their contexts and considering the conditions in which teletandem was implemented in their institutions. This diversity is considered positive for the discussions about mediation because it promotes the participants' awareness of different institutional, cultural and pedagogical implications of teletandem implementation in various universities and language institutes in Brazil and abroad.

The four editions focused in this article were important to integrate the mediators in a collaborative community of analysis and discussion based on the reality of each institutional scenery and to enable the offer of grounded attendance to mediators and teletandem practitioners' needs ${ }^{13}$. They also indicate some challenges for future editions. One of them is the necessity of promoting practices of mediation that allow the development of learners' critical linguistic and transcultural awareness, regarding the emergence of issues such as prejudice, stereotypes, racism, social and gender based bias in the discursive constructions through teletandem. This conclusion was constructed in collaboration with the participants of the 2017 course. The second challenge is to increase the number of participants and promote new mediation courses in English and in other languages, to reach a wider community of professors and mediators interested in implementing telecollaborative practices of language learning.

\section{Final Remarks}

The results of this research paper may lead to a reflection about the education of teachers and other professionals in a context that has been less and less marked by geographical barriers, allowing the emergence of telecollaborative contacts through different languages and cultures.

13. Besides these courses, other actions have been taken by the teletandem researchers and promoters, such as regular local and international research events and meetings. The II IMFLIT (International Meeting on Foreign Language Learning in Tandem) was held at the University of Miami in 2018. In 2019 the III Encontro de Pesquisas sobre Teletandem da UNESP e I Seminário Internacional sobre Telecolaboração e Formação de Professores de Linguas took place at UNESP-Assis. 
As we have discussed, the institutional modality of teletandem has been benefited by the development of different tools that can be used for the mediation and management of the partnerships, for example, Zoom, Facebook Groups and WhatsApp. This diversity of resources has allowed the adjustment of teletandem for different contexts of mediation, considering the growing number of teletandem modalities. We also discussed the challenges of dealing with the diverse conditions for the practice of mediation. These conditions range from management issues regarding different curriculums, type of teletandem participation, availability of mediators and choice of contexts and activities for mediation to power issues in the relationships between the institutions and between the teletandem students.

Promoting a continuous professional development is a necessity to help language educators to deal with the innovations and challenges of intercultural communication in telecollaborative learning contexts (O’Dowd, 2015).

The description of the courses presented throughout this work aimed at providing an overview of the practices for teacher education in the context of teletandem. Our analysis was based on our participation in the courses as members of the organizing committee, professors, mediators and researchers in the Teletandem Brasil program. In this article, we focused on the structural design and management aspects of the courses. Due to this delimitation, we did not intend to do an extensive analyses of the data generated by promoters and participants and of the theoretical foundation and principles that grounded the courses. However, we expect that future researches carry on more detailed analysis of participants' responses to the content of mediation courses and the outcomes of this type of action for their development as mediators.

Considering the goals of this article, we hope it can contribute to the development of innovative practices and contexts for language learning and teacher education through teletandem. We also highlight the importance of understanding the specificities of mediation in different contexts, due to the conditions and resources available for learners and mediators. Finally, we emphasize the role of mediation courses as contexts for the discussion and implementation of improvements in mediation processes based on research findings, observation and grounded analysis. 


\section{References}

ARANHA, S.; CAVALARI, S. M. S. 2014. A trajetória do projeto Teletandem Brasil: da modalidade institucional não-integrada à institucional integrada. The ESPecialist, 35(2), pp. 183-201.

AVALOS, B. 2011. Teacher professional development in Teaching and Teacher Education over ten years. Teaching and Teacher Education, 27, pp. 10-20.

BEDRAN, P. F. 2008. A (re)construção das crenças do par interagente e dos professores mediadores no teletandem [Dissertação de Mestrado em Estudos Linguísticos, Universidade Estadual Paulista, UNESP, São José do Rio Preto].

BELZ, A. J. 2003. Linguistic Perspectives on the Development of Intercultural Competence in Telecollaboration. Language Learning \& Technology, 7(2), pp. 68-117.

. 2003a. From the special issue editor. Language Learning \& Technology, 7(2), pp. 2-5.

BELZ, J. A.; VYATKINA, N. 2008. The Pedagogical Mediation of a Developmental Learner Corpus for Classroom-Based Language Instruction. Language Learning \& Technology, 19(1), pp. 33-52.

BELZ, J. A.; THORNE, S. L. 2006. Introduction: Internet-Mediated Intercultural Foreign Language Education and the Intercultural Speaker. In: J. A. Belz \& S. L. Thorne (Eds.). Internet-Mediated Intercultural Foreign Language Education. Annual Volume of the American Association of University Supervisors and Coordinators (pp. IIXX-XXV), Heinle \& Heinle.

BRAMMERTS, H. 2003. Autonomous language learning in tandem. In: T. Lewis \& L. Walker (Eds.). Autonomous Language Learning InTandem (pp. 27-36), Academy Electronic Publications.

BROCCO, A. S. 2009. A gramática em contexto teletandem e em livros didáticos de português como língua estrangeira [Dissertação de Mestrado em Estudos Linguísticos, Universidade Estadual Paulista, UNESP, São José do Rio Preto].

CANDIDO, J. 2010. Teletandem: Sessões de orientação e suas perspectivas para o curso de Letras [Dissertação de Mestrado em Estudos Linguísticos, Universidade Estadual Paulista, UNESP, São José do Rio Preto].

CAVALARI, S. M. S. 2009. A auto-avaliação em um contexto de ensinoaprendizagem de línguas estrangeiras em tandem via chat [Tese de Doutorado em Estudos Linguísticos, Universidade Estadual Paulista, UNESP, São José do Rio Preto]. 
2018. Integrating telecollaborative language learning into Higher Education: A study on teletandem practice. Brazilian English Language Teaching Journal (Porto Alegre), 9(2), pp. 417-432.

COSTA, L. M. G. 2015. Performatividade e gênero nas interações em teletandem [Tese de Doutorado em Estudos Linguísticos, Universidade Estadual Paulista, UNESP, São José do Rio Preto].

ELSTERMANN, A.K. 2017. Learner Support in Telecollaboration: Peer Group Mediation in Teletandem [Doctoral Dissertation, Bochum: Ruhr-Universität].

FRANCO, G. R. 2016. Aspectos linguísticos emergentes em sessões de teletandem: Uma análise a partir da conscientização da linguagem [Dissertação de Mestrado em Estudos Linguísticos, Universidade Estadual Paulista, UNESP, São José do Rio Preto].

FREITAS, P. C. B. 2015. Pertencer e deslocar virtualmente: Teletandem como espaço antropofágico [Dissertação de Mestrado em Estudos Linguísticos, Universidade Estadual Paulista, UNESP, São José do Rio Preto].

FRESCHI, A. C. 2017. A avaliação por pares no teletandem institucional integrado: Um estudo de caso sobre o feedback linguístico nas sessões orais em português [Dissertação de Mestrado em Estudos Linguísticos, Universidade Estadual Paulista, UNESP, São José do Rio Preto].

FUNO, L. B. A. 2011. Teletandem e formação contínua de professores vinculados à rede pública de ensino do interior paulista: um estudo de caso [Dissertação de Mestrado em Estudos Linguísticos, Universidade Estadual Paulista, UNESP, São José do Rio Preto].

2015. Teletandem: Um estudo sobre identidades culturais e sessões de mediação da aprendizagem [Tese de Doutorado em Estudos Linguísticos, Universidade Estadual Paulista, UNESP, São José do Rio Preto].

FURTOSO, V.A. B. 2011. Desempenho oral em português para falantes de outras línguas: da avaliação à aprendizagem de línguas estrangeiras em contexto online [Tese de Doutorado em Estudos Linguísticos, Universidade Estadual Paulista, UNESP, São José do Rio Preto].

GARCIA, D. N. M. 2010. Teletandem: Acordos e negociações entre os pares [Tese de Doutorado em Estudos Linguísticos, Universidade Estadual Paulista, UNESP, São José do Rio Preto].

. 2012. Ensino/Aprendizagem de línguas em teletandem: espaços para autonomia e reflexão. Estudos Linguísticos, 41, pp. 481-494.

.2013. O que os pares de teletandem (não) negociam. São Paulo: Editora UNESP. 
GARCIA, D. N. M.; SOUZA, M. G. 2018. Teletandem mediation on Facebook. Revista do Gel, 15, pp. 155-175.

KANEOYA, M. C. K. 2008. A formação inicial de professoras de línguas para/em contexto mediado pelo computador (teletandem): um diálogo entre crenças, discurso e reflexão professional [Tese de Doutorado em Estudos Linguísticos, Universidade Estadual Paulista, UNESP, São José do Rio Preto].

LITTLE, D.; USHIODA, E.; APPEL, M. C.; MORAN, J.; O'ROURKE, B.; SCHWIENHORST, K. 1999. Evaluating tandem language learning by e-mail: report on a bilateral project. Trinity College Dublin. $C L C S$ Occasional Paper, 55.

LUZ, E. B. 2009. A construção da autonomia no processo de ensino e aprendizagem de linguas em ambiente virtual (in-teletandem) [Dissertação de Mestrado em Estudos Linguísticos, Universidade Estadual Paulista, UNESP, São José do Rio Preto].

MENDES, C. M. 2009. Crenças sobre a língua inglesa: o antiamericanismo e sua relação com o processo de ensino-aprendizagem de professores em formação [Dissertação de Mestrado em Estudos Linguísticos, Universidade Estadual Paulista, UNESP, São José do Rio Preto].

MESQUITA, A. A. F. 2008. Crenças e práticas de avaliação no processo interativo e na mediação de um par no tandem a distância: um estudo de caso [Dissertação de Mestrado em Estudos Linguísticos, Universidade Estadual Paulista, UNESP, São José do Rio Preto].

O'DOWD, R. (Ed.). 2007. On-line intercultural exchange: A practical introduction for foreign language teachers. Multilingual Matters.

O’DOWD, R. 2015. Supporting In-Service Language Educators in Learning to Telecollaborate. Language Learning \& Technology, 19(1), pp. 63-82.

. 2018. From telecollaboration to virtual exchange: state-of-theart and the role of UNICollaboration in moving forward. Journal of Virtual Exchange, 1, pp. 1-23. Research-publishing.net. https://doi. org/10.14705/rpnet.2018.jve.1

O'DOWD, R.; BEAVEN, A. 2019. Examining the impact of virtual exchange: An exploration of where virtual exchange belongs in institutional strategy. Forum, winter, pp. 14-16.

O'DOWD, R.; RITTER, M. 2006. Understanding and Working with Failed Communication in Telecollaborative Exchanges. CALICO Journal, 23(3), pp. 623-642.

ROSSI DOS SANTOS, G. 2008. Características da interação no contexto de aprendizagem in-tandem [Dissertação de Mestrado em Estudos 
Linguísticos, Universidade Estadual Paulista, UNESP, São José do Rio Preto].

SALOMÃO, A. C. B. 2008. Gerenciamento e estratégias pedagógicas na mediação dos pares no teletandem e seus reflexos para as práticas pedagógicas dos interagentes [Dissertação de Mestrado em Estudos Linguísticos, Universidade Estadual Paulista, UNESP, São José do Rio Preto].

.2012. A cultura e o ensino de língua estrangeira: Perspectivas para a formação continuada no projeto teletandem [Tese de Doutorado em Estudos Linguísticos, Universidade Estadual Paulista, UNESP, São José do Rio Preto].

SCHWIENHORST, K. 1998. Matching pedagogy and technology Tandem learning and learner autonomy in online virtual language environments. In: R. Soetaert; E. De Man \& E. Van Belle (Eds.). Language Teaching On-Line (pp. 115-127). Ghent: University of Ghent.

SILVA, A. C. 2008. O desenvolvimento intra-interlingüistico in-tandem a distância (português e espanhol) [Dissertação de Mestrado em Estudos Linguísticos, Universidade Estadual Paulista, UNESP, São José do Rio Preto].

SILVA, K. A. 2010. O professor mediador e os interagentes (brasileiro e estrangeiro) no projeto 'Teletandem Brasil: línguas estrangeiras para todos': legitimação de crenças elou (re) construção de competências? [Tese de Doutorado em Estudos Linguísticos, Universidade Estadual Paulista, UNESP, São José do Rio Preto].

SOUZA, M. G. 2016. Teletandem e mal-entendidos na comunicação intercultural online em língua estrangeira [Tese de Doutorado em Estudos Linguísticos, Universidade Estadual Paulista, UNESP, São José do Rio Preto].

TELLES, J. A. 2006. Projeto Teletandem Brasil: Linguas Estrangeiras para Todos - Ensinando e Aprendendo línguas estrangeiras in-tandem via MSN Messenger. Faculdade de Ciências e Letras de Assis, UNESP. . 2015. Teletandem and performativity. Revista Brasileira de Linguística Aplicada, 15(1), pp. 1-30.

TELLES, J. A.; FERREIRA, M. J. 2011. Teletandem: Possibilidades, dificuldades e abrangência de um projeto de comunicação online de PLE. Horizontes em Linguística Aplicada (UnB), 9, pp. 79-104.

VASSALLO, M. L. 2010. Relações de poder em parcerias de teletandem [Tese de Doutorado em Estudos Linguísticos, Universidade Estadual Paulista, UNESP, São José do Rio Preto]. 
VASSALLO, M. L.; TELLES, J. A. 2006. Foreign language learning in-tandem: Theoretical principles and research perspectives. The ESPecialist (PUC-SP), 27(1), pp. 83-118.

2009. Ensino e aprendizagem de línguas em tandem: princípios teóricos e perspectivas de pesquisa. In: J. A. Telles (org.). Teletandem: um contexto virtual, autônomo e colaborativo para aprendizagem de línguas estrangeiras no século XXI (pp. 21-42), Pontes Editores/ FAPESP.

VYGOTSKY, L. S. 1991. A formação social da mente: o desenvolvimento dos processos psicológicos superiores (4. Ed). São Paulo: Martins Fontes.

WARE, P. D.; KRAMSCH, C. 2005. Toward an Intercultural Stance: Teaching German and English through Telecollaboration. The Modern Language Journal, 89(2), pp. 190-205.

WELSCH, W. 1994. Transculturality: the puzzling form of cultures today. California Sociologist, 17(18), pp. 19-39.

ZAKIR, M. A. 2015. Cultura e $(m)$ telecolaboração: uma análise de parcerias de teletandem institucional [Tese de Doutorado em Estudos Linguísticos, Universidade Estadual Paulista, UNESP, São José do Rio Preto].

ZAKIR, M. A.; COLONHEZE, T. O. (Mimeo). Projeto Teletandem na UNESP-Assis: um mapeamento das parcerias institucionais.

Recebido em: 29/01/2020

Aprovado em: 16/07/2020 